\section{The political economy of peacebuilding: The case of women's cooperatives in Nepal}

\section{Smita Ramnarain}

P eacebuilding occupies a significant place in the international development exicon. Espousing democratization, free and globalized markets, the rule of law, human rights, and neoliberal development, critics argue that the liberal peace model that informs most peacebuilding efforts bases itself on the ostensible success of liberalism in Western economies and seeks simply to transplant these ideas to the lagging global South. As such it remains ethnocentric, noninclusive of local context or ownership, and is imposed from above. The search for alternatives to a top-down, liberal model of peace has led to appeals to develop grassroots, locally-led, bottom-up approaches to peacebuilding. Given the emphasis that is placed on the economic restructuring of postwar societies as part of a liberal reconstruction package, an alternative, bottom-up approach to peacebuilding necessitates an alternative grassroots economics, and political economy, of peace. This article contributes to the discussion on alternative approaches to the political economy of peacebuilding. It uses a case study of (women's) savings and credit cooperatives (SACCOs) building peace in local communities in postwar Nepal. I argue that bottom-up, local endeavors can carve out spaces to negotiate the meanings and processes of peace by refocusing attention on underlying endemic structural violence that may have given rise to war in the first place, thereby problematizing the "post" in postwar peace (or post-conflict peace, as the literature usually puts it). At the same time, I argue that the existence of such alternative efforts within a largely liberal, top-down peacebuilding universe poses context-specific challenges for their continued effectiveness. ${ }^{1}$

Nepal emerged from a decade-long Maoist-inspired war in 2006 when a comprehensive treaty was signed between rebels and government. This People's Revolution led to the abolition of the 240-year-old monarchy and to democratic elections, in 2008, for the formation of a Constituent Assembly tasked with writing the constitution for the new (Naya) Republic of Nepal. Since this time, Nepal has faced immense political instability, the eruption of new localized conflicts in the Terai (plains) region, and has yet to make significant progress on writing the constitution. ${ }^{2}$ Nepal also has a long history of involvement by international development NGOs and foreign aid organizations, including the UN and the World Bank. In the postwar period, these organizations provided extensive support for Nepal's integrative peace process through reconstruction and peacebuilding programs.

During the Maoist insurgency, large and formal institutions, especially those associated with foreign aid or development organizations, came under attack for being "anti-poor". 3 So did exploitative moneylenders who operated in rural areas and charged interest rates ranging from 36 to 100 percent. In contrast, grassroots organizations perceived to be inclusive and transparent, credit cooperatives focusing on women and the marginalized in particular, were allowed to operate in most war-affected areas. In the aftermath, SACCOs have provided economic alternatives to communities. A few of them also emerged as grassroots peace constituencies to mitigate the effects of conflict and of structural violence and partnered with larger development organizations for peacebuilding and reconstruction activities in local communities. ${ }^{4}$

This article is based on fieldwork carried out in nine districts of Nepal in January and February 2011. Using ethnographic methods - in-depth, open-ended interviews of cooperatives' leadership (board of directors or executive committee), group discussions and interviews with members, onsite observations, and textual analysis of primary and secondary literary sources (reports, memos, news articles) - the grassroots efforts of cooperatives to articulate an alternative vision of peace through their everyday activities is documented. Through their activities such as the provisioning of credit and services, health and child care, open membership, and engagement with structural injustices affecting their membership body, they are able to formulate a political economy of peacebuilding that emphasizes local agency and collective action. At the same time, the cooperatives also exist within the context of an overarching liberal postwar development paradigm and dialogue with international donor agencies who represent this paradigm. As such, even as they provide an alternative to the liberal, top-down model, they face constraints in terms of their scale and scope, especially when operating within a short-term-oriented aid structure that oversees postwar development. ${ }^{5}$

The article is organized as follows: The first section briefly discuss the hegemonic liberal model of peacebuilding and reviews the literature on the impact of (neo)liberal policies on war-torn economies. This motivates, second, a discussion of an alternative political economy of peacebuilding and socioeconomic reconstruction, specifically a bottom-up, grassroots approach. The third section focuses on SACCOs in Nepal, detailing their perspectives on peace and interventions to address structural violence, discrimination, and social exclusion in the aftermath of violence. The fourth section undertakes a critical examination of the successes and shortcomings of SACCOs in 
building peace, including their complex relationship to top-down aid structures. I conclude by suggesting that despite their constraints, cooperatives can function as springboards for a peace that can "reflect local adaptations and resistance to foreign presence ... by alternative concepts of intervention."

Hegemonic, liberal peacebuilding

The notion of peacebuilding gained currency in international relations in the 1990s in response to the post-cold war spread of political instability and violent intrastate conflict in newly formed, newly liberated, and newly democratized countries of the global South. The erstwhile Secretary General of the UN, Boutros-Ghali, in his report, An Agenda for Peace, argued that while short-term humanitarian relief, rehabilitation, and crisis intervention were important, they were not enough in societies persistently "threatened by brutal ethnic, religious, social, cultural or linguistic strife." Instead, the emphasis should be on identifying and supporting structures that increase these societies' capacities for conflict resolution and the building of sustainable peace. Peacebuilding is to involve a comprehensive set of strategies, approaches, processes, and stages needed for the social transformation of a conflict-affected society toward more sustainable, peaceful relationships. ${ }^{7}$

The term peacebuilding, as initially featured in the literature, aimed at decentralizing social and economic authority and "bottom-up" mitigation of endemic structural violence. But since being adopted by international organizations doing development work in war-torn countries - most prominently the UN, the UNDP, the World Bank, and the IMF, and by bilateral development agencies such as UK's Department for International Development (DfID), the Canadian International Development Agency (CIDA), and the United States Agency for International Development (USAID) among others - a "top-down", donor-driven perspective prevails. This top-down model adheres to a broader liberal paradigm, the focus of much work in international relations and peace studies. Based on a premise that democracies seldom go to war, this paradigm emphasizes good governance, law, democracy, development, and constitution-building without questioning the validity of these components or the motivations of its agents. The perceived success of liberal market democracy in the First World meant that its near-universal adoption was the "natural" solution to endemic violence, with little discussion of alternatives. The export of liberal democracy to war-torn states went hand-in-hand with a movement toward market-oriented economics as well. Central to the now near-hegemonic, liberal, postwar peace model is the assumption that as long as security can be provided, the benefits of top-down democratization and marketization will inevitably trickle down and galvanize the grassroots. ${ }^{8}$

Critical scholars question these premises. They point not only to the general conceptual ambiguity and rather broad rubric of liberal peacebuilding but also to the distinctly illiberal outcomes of the top-down peace project in conflict-affected and recovering states. The experiences of conflict-torn states with the liberal economic package have been especially revealing: The very economic and political interventions purported to bring peace have destabilized war-affected states. One scholar discusses the adverse effects of fast-tracking decentralization in the politically charged atmosphere of Sierra Leone and the new divisions the process produced. In the Balkans, the Dayton Accord sought to transform Bosnia to a liberal democracy with an explicit commitment to free market principles in the constitution. However, the austerity policies, currency devaluation, trade and price liberalization, and removal of food subsidies that followed led to a rise in unemployment, social polarization, and heightened tensions. In Timor-Leste, the failure of the liberal peace project has been attributed to its lack of attention to the welfare requirements of the new state's citizens. Evidence from Iraq and Afghanistan points to the failure of the liberal peace model and its associated neoliberal economic policies to ensure lasting peace. In short, liberal, top-down peacebuilding and postwar reconstruction has come under fire for reflecting the ideological and practical interests of the global North, regardless of cost, and for its evasion of issues around persistent forms of structural violence in societies recovering from violence. ${ }^{9}$

\section{Alternatives to top-down peacebuilding}

In acknowledgment of these critiques, there has been a growing interest — on the part of international development agencies as well as by scholars and practitioners - in viable alternative approaches that explore the possibility of an organic peacebuilding politics, one that can impart a genuine sense of civic participation and responsibility, i.e., peacebuilding from below.

First, peacebuilding from below, or bottom-up, implies that its strategies must be devised by local actors, use local resources, and be adopted with a sense of local ownership. Similarly, others argue for a community-based, bottom-up peacebuilding based on participatory processes, so that people most affected by violence can find and articulate the most appropriate and effective solutions for their context. In moving beyond liberal peace and in expressing a growing interest in "the political economy of the grassroots levels," bottom-up peacebuilding departs from orthodoxy without precluding its use. Rather, scholars and practitioners suggest a reorientation of the top-down approach, even perhaps the coexistence of liberal and communitarian approaches in a hybrid space. ${ }^{10}$

Second, a realization prevails that alternative approaches to peacebuilding cannot emerge without an alternative economics and political economy of peace. Some recent works have taken steps in this direction. One critiques the imposition of peace conditionalities - formal performance criteria and informal policy dialogue - on war-torn countries, arguing that these ignore the insidious political repercussions of conditionality. Significant reform of the aid sector in humanitarian and peacebuilding contexts is called for. Another argues that support of social recovery is more essential 
and effective than reconstruction and stabilization. Yet another proposes an active role for the state in postwar reconstruction. All these focus largely on the macroeconomy and retain emphasis on postwar interventions, operationalized by international or state actors. ${ }^{11}$

A third, and relatively underresearched, approach that is emerging from the interdisciplinary terrain of development studies and political economy focuses on building an alternative economics of peace from the ground up through attention to community-based organizations, especially organizations of a cooperative nature. Self-help cooperatives have been especially important in conflict-torn or conflict-prone economies, especially when such economies lack a cohesive or stable central authority. In such cases, self-help cooperatives or community-based organizations can form the nucleus of an alternative political economy of peacebuilding. Economic studies in other contexts have emphasized the importance of such initiatives in situations of crisis, where community organizations have supported livelihoods, provided essential services such as insurance against risk, and supported small-scale private enterprise. The success of the Mondragon worker cooperatives in the aftermath of the Spanish civil war in mitigating widespread unemployment, low levels of education, and general postwar malaise in the Basque region provided an early example of the significant role cooperatives could play in restoring postwar economies. More recently, experiments in the former Yugoslavia (Montenegro and Macedonia) find that farmer cooperatives enabled the reconstruction of livelihoods and acted as "ethnic bridging institutions" with leadership drawn from a variety of communities. In the post-genocide period, agricultural cooperatives in Rwanda have brought about community reconciliation, besides ensuring their livelihoods options. Similarly, cooperative experiments in several conflict-affected contexts in East Asia and Central America show replenished social capital, restored interpersonal relationships, and a renewed sense of participation and inclusion among members. The interest in community-based initiatives such as self-help cooperatives emerges, therefore, from the twin objectives of bottom-up peacebuilding: ensuring economic recovery as well as socially inclusive and locally-owned peace processes. ${ }^{12}$

Women's SACCOs and positive peace in postwar Nepal

Although some also provide legal advice, health care, and literacy services, women's SACCOs in Nepal are primarily credit unions providing banking and insurance services. They are nonprofit, community-based organizations owned and managed by their members. SACCOs follow the Rochdale principles of nondiscrimination and inclusion, in membership as well as in cooperative leadership. The ability of SACCOs to operate during the war meant that they were a crucial component of members' livelihood strategies, assisting women and conflict-affected communities in rural areas with the provision of credit services, livelihood programs and training, and emotional support against abuse, persecution, and violence during conflict. In the aftermath,
SACCOs used their reputation and networks in their respective communities to emerge as platforms for peacebuilding and to continue working on socioeconomic reconstruction. ${ }^{13}$

The objective of field research in Nepal was to examine the spillover effects of SACCOs as platforms for peace and reconstruction. In interviews and focus group discussions, conducted in early 2011, to look into the processes of bottom-up peacebuilding, participants interpreted "conflict" broadly, to include not only overt violence as had taken place in the civil war, but also structural violence, including domestic violence and strife, caste-based discrimination, class-based exploitation, and gender inequalities. SACCO members frequently drew a link between the overt manifestations of violence in Nepal - the Maoist insurgency, the Terai conflicts, and the frequent political violence that erupted in the postwar period-and the endemic structural injustices driving direct violence. ${ }^{14}$ As one member stated:

We start at the grassroots level in our politics and argue for social change. We advocate for social equality because peace cannot prevail where there is social injustice. Social help is the base of all good and positive politics, and positive peace.

Gender and caste-based discrimination received the most attention in the actions of SACCOs due to their immediate pertinence to cooperative members' everyday lives at the household (micro) and community (meso) levels (see Figure 1), and their links to direct personal and societal violence. The desire to make cooperatives a safe and equal space for all women in the newly democratic Nepal emerged not only from idealism but also from a pragmatic recognition that mitigating conflict and promoting social unity is a necessary condition for economic prosperity. Discussions with women members highlighted the ways in which SACCOs contributed to household survival and to women's increased bargaining power within the household. However, SACCO leaders were quick to recognize that the benefits of cooperative membership went beyond the economic realm. While it was acknowledged that material resources and development, or progress (bikas, in Nepali), was important, members articulated a vision of development that was wellbeing-oriented, inclusive, and which provided protection for the most vulnerable. The heavy involvement of foreign capital in Nepali development attracted cynicism from SACCO members. Locally-based cooperatives, on the other hand, were considered to be vehicles of self-reliance, education, and information, especially for women in rural areas. Because of their investment in local communities, members argued that SACCOs could intervene effectively at the micro and meso levels to prevent violence and to build peace. ${ }^{15}$

Cooperatives attempted to address the issue of ethnic and caste-based discrimination through outreach activities - awareness campaigns and community mobilization - seeking representation of women from the Dalit (so-called low caste) and Janjati (indigenous) communities in SACCO membership and leadership. 
Age-old traditions such as the practice of untouchability still grip many communities in Nepal. However, cooperatives themselves have emerged as sites of nondiscrimination, democracy, and egalitarianism, as well as of education and consciousness-raising, in order to battle prevalent caste oppressions. The commitment of the SACCOs to the Rochdale principles of nondiscrimination was upheld through everyday actions such as sitting or eating together. Members engage with their own households and the larger community on matters of gender, caste, religious, and ethnic discrimination, emphasizing the importance of "moving with the times" in the new Nepal. Class-based exploitation, namely instances of debt bondage, could be addressed due to the lower rates of interest on cooperative loans than on those charged by rural moneylenders. SACCO members frequently recognized the immense challenges that social inclusion posed for them, especially in including Dalit, but were hopeful that sustained efforts would bear fruit. ${ }^{16}$

SACCOs attempted to tackle gender-based discrimination by campaigning for women's access to education, citizenship rights, and ownership of property. SACCOs set up paralegal teams to provide legal counsel and obtain justice for survivors of domestic violence or gender-based abuse, such as the persecution of widows. In the run-up to the Constituent Assembly elections, SACCOs worked for women's representation in the Assembly and for their rights to citizenship and property in the new constitution. In the political domain, SACCOs remained impartial and nonpartisan which helped to establish their credibility as inclusive community organizations. There was a sense of ownership and pride among members of the contributions to local reconciliation and peacebuilding, especially through community engagement, made by the SACCOs' concerted actions, despite frustration with the slow progress on constitution writing and the lack of political stability. Members commented that the sense of community imparted by cooperative membership was a source of security in "changeable times." 17

Winds of change? Critical perspectives on the political economy of bottom-up peacebuilding

The experiences of women's SACCOs in Nepal illustrate the possibility of an alternative discourse of peace, a bottom-up approach linking economic with social objectives in peacebuilding processes. Besides providing livelihood options to their members, SACCOs in Nepal have drawn links between deprivation and violence and redirected attention to structural injustices that are root causes of violence. They challenge the liberal conception of the "post" in postwar as a finite, irreversible period of time where the root causes of violence have been obliterated. They espouse a holistic and emancipatory approach to social peace, one focusing on the needs of everyday life and critical of patriarchy and discrimination, rather than a band-aid approach that only addresses overt symptoms of violence. By privileging local needs and agency in their strategies for peacebuilding, actively seeking the inclusion of

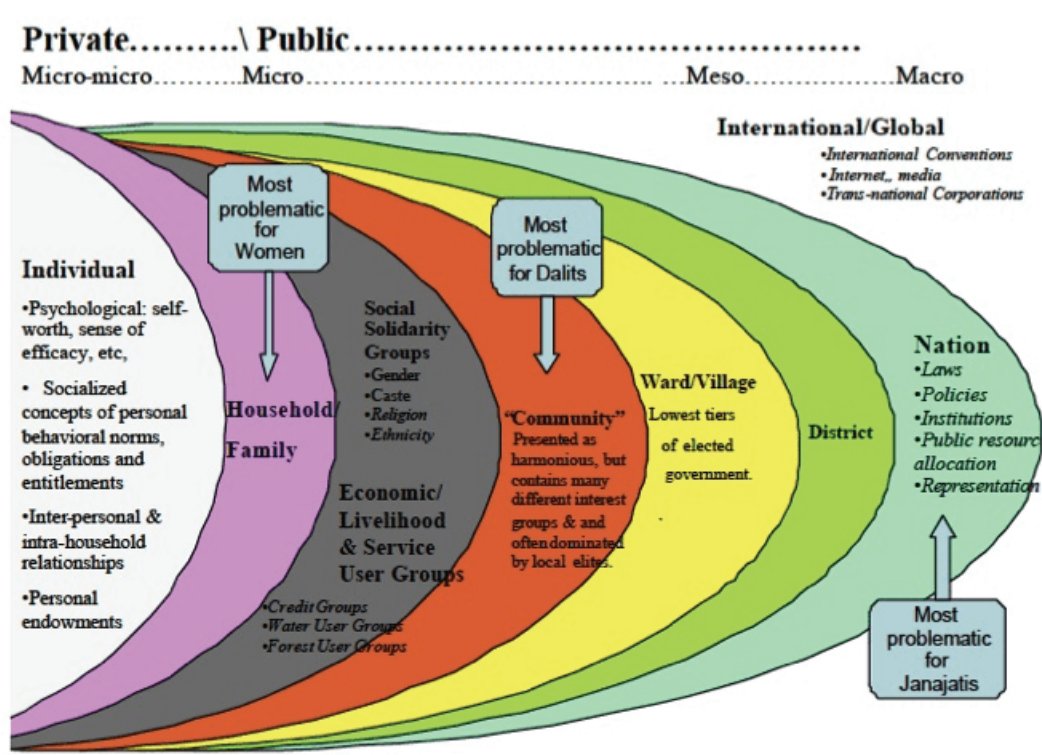

Figure 1: Sites of empowerment and inclusion.

Source: Bennett (2005).

marginalized groups, providing platforms for reconciliation, consciousness-raising and empowerment, and affording economic strategies to address the material needs of members, SACCOs have tried to expand the definition and the agenda of peace to include social justice. In this articulation, social justice and equality are seen as essential components of peace, reflecting the distinction drawn by Johan Galtung between positive and negative peace. While peace could simply mean the absence of violence (a negative peace for Galtung), SACCOs go beyond this definition to articulate a "positively defined condition" for peace, i.e., the absence of structural violence and an egalitarian distribution of power and resources. ${ }^{18}$

Yet, romanticizing cooperatives' role in conflict transformation and peacebuilding is problematic. Cooperatives, as community-based organizations placed within both a conflict-affected and a liberal milieu, face limitations and challenges. For one, although arguably successful in mediating boundaries of caste, ethnicity, and creed, the membership bodies of cooperatives may not be entirely impervious to divisive pressures along these lines. Being community organizations, cooperatives' membership bodies can reflect ethno-nationalism, be susceptible to elite capture, or be at risk of fostering relationships of superiority and condescension among (groups of) members, especially if membership is heterogeneous. The history of the 
cooperative and the commitment of its members to uphold equality and social unity contribute to the ability of the cooperative to deal with these pressures. The SACCOs in Nepal only had mixed success in this task: Some SACCOs were able to foster dialogue on ethnic and caste equality and ensure equal representation in the governing bodies, while others reflected clear divisions between leadership and membership. Some SACCOs articulated social goals and a desire to provide alternatives for women. These SACCOs integrated their financial and social activities (4 out of 12 visited for this study). The majority, however, were preoccupied with financial sustainability and were narrow in their scope: They only took on advocacy activities when they received special funds for these (from international donors) and these activities were limited in scope (such as training and workshops during a specific project period). ${ }^{19}$

A second issue emerges with the complex relationship of cooperatives to international development organizations and, more broadly, to the liberal peace project. From the perspective of international development organizations, Nepal's SACCOs afford opportunities to mainstream local participation into liberal peacebuilding. The cooperatives envisage an alternative political economy of peacebuilding, but this has not precluded their obtaining funds from international organizations for livelihood or peacebuilding projects at various times, especially in the context of ever-declining state support and a constant shortage of resources. Nepal's SACCOs have frequently functioned as receptacles for liberal peacebuilding interventions, for instance through providing a ready-made audience for top-down peace education, consciousness-raising, and democratic education workshops, and have been platforms for social engineering in the postwar context. SACCOs that did not explicitly include transformative goals in their cooperative charter would nevertheless undertake short-term programs on peacebuilding, conflict mediation, and democratic education if these projects were being funded by international donors. In such cases, however, the agenda was set by international donors and the SACCOs were simply the delivery mechanism. SACCO leaders were skeptical about the role of international organizations, highlighting the disjunction between SACCO's longer-term efforts to deal with structural violence and the short-term priorities of funders. Most "toed the line," however, in order to retain their access to funds. As other authors have observed, local actors in a heavily developmentalized context such as Nepal are all too aware that being too critical of donors would simply drive them to a "more compliant local" that does not make implementation too difficult. Many SACCOs are caught in this very trap. ${ }^{20}$ As one SACCO secretary put it:

We do our best ... Sometimes we have to compromise. If we don't find a common ground, the funds will go elsewhere and then, who knows ... At least we try to make sure that we do some good. When we are given some funds, we try our best to allocate them to the uses that we think will be most appropriate for our needs.
A related concern is that while collective action is a radical strategy used by cooperatives to address local problems, their efforts seem to largely focus on helping communities survive the postwar, liberal transition through self-help, rather than advocate for a paradigm shift. Even as they target structural injustices, the mechanisms by which poverty and inequality are perpetuated have escaped scrutiny. Ironically, liberal elements creep into the terrain of cooperatives, manifested in their advocacy for women's ownership of property, even as they have supported communa forms of property ownership. SACCOs have actively participated in liberal peace education programs aimed at constructing "good citizens" in the new democracy. The perception also prevails that the state is an unreliable or corrupt actor, which is in tune with the liberal idea of a minimalist state. As cooperatives attempt to fill the gaps in postwar governance through local provisioning, they thus retain a complex relationship to liberal structures, resisting as well as reinforcing liberal principles. ${ }^{21}$

Despite incorporating radical notions of empowerment in their everyday actions, the cooperatives remain localized, not only lacking the critical mass to be full-fledged alternatives to liberal peace and development, but also cooperating with the libera machinery as one strategy for organizational survival.

\section{Conclusion}

Are cooperatives successful in formulating a political economy of postwar peacebuilding that is truly grassroots-oriented? The liberal discourse on peace has largely focused on macroeconomic restructuring in war-torn states rather than the protection of the poor and it has assigned responsibility to war-torn states for recovery without transferring to them the corresponding power for self-determination. The discursive hegemony that the liberal model has enjoyed means that the very existence of cooperatives as alternative spaces for grassroots peacebuilding provides fodder for optimism. For one, through their focus on endemic structural violence, SACCOs have highlighted the limitations of the liberal model and its myopic, "quick-fix" approach to peacebuilding and postwar reconstruction. Cooperatives potentially articulate a grassroots political economy of peacebuilding that builds the basis for more sustainable forms of peace, based on social justice, not simply the absence of violence. For another, cooperatives provide a platform that allows individuals and communities to "live and develop political strategies in their local environment" through their everyday actions and address local economic needs through provisioning for these needs as in cases of gender-based violence that threatens local communities. At the very least, the experiences of cooperatives inform discussions on the potential for hybrid forms of peacebuilding to emerge, through local adaptations of and responses to top-down directives. ${ }^{22}$

While cooperatives can allow for peace agendas to be formulated through bottom-up processes, the experiences of SACCOs raise further questions for the role of "the local." An overly sanguine view of the local as a remedy and counterbalance 
to the domination of the global is problematic, not least due to the unequal configuration of power the two are placed in. On the one hand, grassroots organizations must be alert to local hierarchies coopting their goals. On the other hand, the increased interest of global players in the local, and the lure of resources available through these players, impose new threats on slow-simmering, organic, community-based organizations, whose transformative processes always run the risk of being captured by external interests. Established grassroots cooperatives are better positioned to negotiate terms and resist impositions. Fledgling organizations such as the majority of Nepal's SACCOs face significant challenges, especially in the context of postwar scarcity.

Ultimately, deeper explorations are required of the complex ways in which the local interacts with the global, and of how viable resistance to the liberal model can be formulated in the postwar terrain.

\section{Acknowledgment}

I thank the Canadian Cooperatives' Association (CCA) for allowing the use in this article of interview and focus group data first collected for CCA.

Notes

Smita Ramnarain is an Assistant Professor of Economics at Siena College, NY, USA She may be reached at $<$ sramnarain@siena.edu $>$.

1. Espousing: Herring (2008, p. 48). Critics: Donais (2009). From above: Mac Ginty (2010); Donais (2009). Appeals: Lederach (1997). Emphasis on economic restructuring: Pugh (2005); Herring (2008). Alternative economics: Pearce (2005).

2. The Constituent Assembly, formed after the cease-fire in 2008, was dissolved on 27 May 2012. Elections for the new Constituent Assembly have been postponed multiple times and were yet to be held at the time this article was being written.

3. International aid organizations: Examples include the Emergency Peace Support Project (2008-2014) funded by the World Bank's International Development Association, and the United Nations Peacebuilding Fund in Nepal. Anti-poor quote: Wehnert and Shakya (2003).

4. Peace constituencies: The term is used by Lederach (1997) to signify networks of peacebuilding among local actors. Moneylenders: Dhakal (2007, p. 7). Cooperatives allowed: This depended largely on the nature of the organization and how it was perceived in the local communities. Transparent, inclusive, and democratic organizations, especially savings and credit cooperatives, were left alone.
Organizations perceived to be instruments of the government of Nepal (GON) such as small farmers' cooperatives (SFCL) under the aegis of Rural Finance Nepal, or those associated with foreign development organizations provoked Maoist ire and were more frequently attacked. See Wehnert and Shakya (2003); interviews conducted by the author corroborate this information.

5. Nine districts: Rolpa, Dang, Chitwan, Kavre, Kathmandu and Lalitpur, Tanahu, Dhading, Morang, and Sunsari. Thirty-two in-depth interviews with SACCO members, fifteen interviews with SACCO leaders, and six focus group discussions were conducted in January 2011. 77 respondents participated in total. Everyday activities: The "everyday" has received attention recently for providing the basis for resistance to the liberal peacebuilding project. For a detailed and fascinating study of the "everyday" in peacebuilding praxis, see Richmond (2010).

6. Quote: Pugh (2011, p. 308).

7. Boutros-Ghali and quote: Boutros-Ghali (1992, p. 3). Comprehensive set of strategies: Lederach (1997).

8. Structural violence: Galtung (1969) elaborated on a difference between direct violence and structural violence. While direct violence is the result of overt conflict, Galtung pointed to the violence that social structures and institutions may perpetrate on individuals resulting in their inability to meet their basic needs and achieve their potential. Structural violence could include exploitation, discrimination, sexism, racism, nationalism etc. Although it is logically possible for structural violence and direct/personal violence to exist without the other, the two are highly interdependent, i.e. "one shades into the other" (Galtung 1969, p. 182). Also see Galtung (1976). Development agencies: Barnett, et al. (2007); Paris (2004). Democracies seldom go to war: Paris (2004, p. 41). No questioning paradigm validity: Richmond (2006). Movement toward market-oriented economies: Paris (2004); Pugh (2005). Marketization: Indeed, given the specific concerns of war economies - namely that war leads to economic activity that is contingent upon its own continuation - the economic aspects of peacebuilding have lately been emphasized as vital in ending war and reaching sustainable peace (EPIC, 2007, in Herring, 2008). Trickle down: Richmond (2009).

9. Conceptual ambiguity: Goodhand and Lewer (1999). Distinctly illiberal: Goodhand and Walton (2009); Donais (2009). Sierra Leone: Fanthorpe (2006). Bosnia: Woodward (1995). Timor-Leste: Richmond and Franks (2008). Iraq: Dodge (2010); Herring (2008). Afghanistan: Suhrke (2008). Ideological and practical interests: Klein (2007); Guttal (2005). Evasion of issues: Pugh (2005); Mac Ginty (2010). 
10. Organic peacebuilding and local ownership: Lederach (1997, esp. p. 242) Participatory processes: E.g., Paffenholz (2003). Pugh: (2005, p. 12). Hybrid space: Mac Ginty (2010); Donais (2009); Pugh (2011).

11. Alternative economics of peace: Pearce (2005); Pugh (2005). Peace conditionalities: Boyce (2002). Social recovery: Brauer and Dunne (2012). Yet another: Ballentine and Sherman (2003).

12. Importance of self-help: Pugh (2005). Situations of crisis: Herzberg (2007); Glennester, et al. (2011). Mondragon: Whyte and Whyte (1991). Former Yugoslavia: Weihe (2004, p. 1). Rwanda: Sentama (2009). East Asia and Central America: Examples are in Parnell (2003).

\section{SACCOs during the war: Shima and Ghale (2007).}

14. It is important to note here that despite the nearly universal agreement of SACCO members that peace includes the absence of structural violence, the actual degree to which SACCOs took on a social role alongside the economic one varied widely. Out of twelve SACCOs visited in nine districts, only four explicitly articulated their transformatory social goals in their charters. The remaining eight engaged in advocacy only occasionally, and on a case-by-case basis. These caveats will be taken up for discussion in the next section.

15. All statements in this paragraph are based on interviews and focus groups. SACCO representatives were also aware of the limitations of locally-based initiatives to influence the macro level. These issues will be taken up in the next section.

16. "Moving with the times" quote: From a SACCO member in a focus group discussion. Immense challenges: For instance, SACCO members in Chitwan district commented on efforts that were underway to integrate a nearby Chamar (also a so-called low caste) community into their membership body. Similarly, cooperatives in the Terai (plains) acknowledged the imbalances in cooperative leadership between the so-called upper castes (who were dominant) and the Madhesi castes (indigenous to the plains).

17. Gender-based discrimination and property ownership: Interviews of SACCO leaders in Dhading Besi, a region with high levels of domestic and gender-based violence; also focus groups in Eastern Nepal with SACCO members, 2011. Run-up to elections: Women frequently need a male guardian to be able to buy, sell, or give away movable property, or to obtain loans. Women must also depend on a male guardian for their citizenship papers. While these laws have been changed on paper, their implementation in Nepal remains mixed. Further, the stalemate in writing the constitution has proved to be a frustrating element for ensuring women's representation in the political sphere. Ownership and pride with contribution: Interviews and author's observations. "Changeable times" quote: Focus group discussions; quote from SACCO member.

18. Challenge liberal conceptions: See, e.g., Moore (2000). Everyday life: Richmond (2010). Galtung and quote: Galtung (1969, p. 183).

19. Ethno-nationalism: Ruwanpura (2007). Be at risk: Mansuri and Rao (2004). Clear divisions: Author's observations from fieldwork in Nepal.

20. Ready-made audience: Also see Ramnarain (2011). Other authors: Miklian, et al. (2011, p. 299),

\section{Self-help: Pugh (2005).}

22. Assigned responsibility: Pugh, Cooper, and Turner (2008). Quote: Richmond (2010, p. 670).

\section{References}

Ballentine, K. and J. Sherman, eds. 2003. The Political Economy of Armed Conflict: Beyond Greed and Grievance. Boulder CO: Lynne Rienner/International Peace Academy.

Barnett, M., H. Kim, M. O’Donnell, and L. Sitea. 2007. 'Peacebuilding: What Is in a Name?" Global Governance: A Review of Multilateralism and International Organizations. Vol. 13, No. 1, pp. 35-58.

Bennett, L. 2005. "Gender, Caste and Ethnic Exclusion in Nepal: Following the Policy Process from Analysis to Action,? Conference Paper: New Frontiers in Social Policy, Arusha. http://www.k4health.org/sites/default/files/Gender,\%20 caste $\% 20$ and $\% 20$ ethnic $\% 20$ exclusion $\% 20$ in $\% 20$ Nepal.pdf [accessed 11 September 2013].

Boutros-Ghali, B. 1992. Report of the UN Secretary-General: An Agenda for Peace. Published 17 June 17 1992. http://www.cfr.org/peacekeeping/report-un-secretarygeneral-agenda-peace/p23439 [accessed 13 July 2013].

Boyce, J. 2002. "Aid Conditionality as a Tool for Peacebuilding: Opportunities and Constraints." Development and Change. Vol. 33, No. 5, pp. 1025-1048.

Brauer, J. and J.P. Dunne. 2012. Peace Economics: A Macroeconomic Primer for Violence-Afflicted States. Washington, D.C.: United States Institute of Peace Press.

Dhakal, N.H. 2007. "Towards Expanding the Frontier of Microfinance Services in Nepal." Paper. International Conference on Rural Finance Research: Bringing 
Research into Policy and Practices, 19-21 March 2007. Rome, Italy: FAO http://www.fao.org/ag/rurfinconference/docs/papers_theme_2/towards_expandi ng the frontier.pdf [accessed on 21 July 2013].

Dodge, T. 2010. "The Ideological Roots of Failure: The Application of Kinetic Neo-liberalism to Iraq." International Affairs. Vol. 86, No. 6, pp. 1269-1286.

Donais, T. 2009. "Empowerment or Imposition? Dilemmas of Local Ownership in Postconflict Peacebuilding Processes." Peace and Change. Vol. 34, No. 1, pp. 3-26.

EPIC [Education for Peace in Iraq Center]. 2007. "National Groups Join with EPIC in Calling for Humanitarian, Economic Surge to Help End Iraq War.” 24 July. For reference, see Herring (2008) below.

Fanthorpe, R. 2006. "On the Limits of Liberal Peace: Chiefs and Democratic Decentralization in Post-War Sierra Leone.” African Affairs. Vol. 105, No. 418, pp. 27-49.

Galtung, J. 1969. "Violence, Peace and Peace Research.” Journal of Peace Research. Vol. 6, No. 3, pp. 167-191.

Galtung, J. 1976. "Three Approaches to Peace: Peacekeeping, Peacemaking, and Peacebuilding," pp. 297-298 in J. Galtung, ed. Peace, War and Defense: Essays in Peace Research, Vol. II. Copenhagen: Christian Ejlers.

Glennester, R., E. Miguel, and K. Casey. 2011. "Reshaping Institutions: Evidence on External Aid and Local Collective Action.” Cambridge, MA: NBER Working Paper 17012

Goodhand, J. and N. Lewer. 1999. "Sri Lanka: NGOs and Peace-Building in Complex Political Emergencies." Third World Quarterly. Vol. 20, No. 1, pp. 69-87.

Goodhand, J. and O. Walton. 2009. "The Limits of Liberal Peacebuilding? International Engagement in the Sri Lankan Peace Process." Journal of Intervention and Statebuilding. Vol. 3, No. 3, pp. 303-323.

Guttal, S. 2005. "The Politics of Post-War/Post-Conflict Reconstruction." Development. Vol. 48, No. 3, pp. 73-81.

Herzberg, B. 2007. "Monitoring and Evaluation During the Bull-dozer Initiative: 50 Investment Climate Reforms in 150 Days. Washington, D.C.: World Bank.

Herring, E. 2008. "Neoliberalism Versus Peacebuilding in Iraq," pp. 47-64 in M. Pugh, N. Cooper, and M. Turner, eds. Whose Peace? Critical Perspectives on the Political Economy of Peacebuilding. Basingstoke: Palgrave Macmillan.

Klein, N. 2007. The Shock Doctrine: The Rise of Disaster Capitalism. London: Penguin.

Lederach, J.P. 1997. Building Peace: Sustainable Reconciliation in Divided Societies. Washington, D.C.: United States Institute of Peace Press.

Mac Ginty, R. 2010. "Hybrid Peace: The Interaction Between 'Top-Down' and 'Bottom-Up' Peace.” Security Dialogue. Vol. 41, No. 4, pp. 391-412.

Mansuri, G. and V. Rao. 2004. "Community-Based and Driven Development.” World Bank Research Observer. Vol. 19, No. 1, pp. 1-39.
Miklian, J., K. Lidén, and Å. Kolås. 2011. "The Perils of 'Going Local': Liberal Peacebuilding Agendas in Nepal." Conflict, Security and Development. Vol. 11, No. 3, pp. 285-308.

Moore, D. 2000. "Levelling the Playing Field and Embedding Illusions: 'Post-Conflict' Discourse and Neo-Liberal 'Development' in War-Torn Africa.' Review of African Political Economy. Vol. 27, No. 83, pp. 11-28.

Paffenholz, T. 2003. Community-based Bottom-up Peacebuilding. The Development of the Life and Peace Institute's Approach to Peacebuilding and Lessons Learned from the Somalia Experience (1990-2000). Uppsala: Life and Peace Institute.

Paris, R. 2004. At War's End: Building Peace After Civil Conflict. Cambridge, UK: Cambridge University Press.

Parnell, E. 2003. "The Role for Cooperatives and Other Self-Help Organizations (SHOs)," pp. 285-308 in E. Date-Bah, ed. Jobs After War: A Critical Challenge in the Peace and Reconstruction Puzzle. Geneva: ILO.

Pearce, J. 2005. "The International Community and Peacebuilding." Development Vol. 48, No. 3, pp. 41-49.

Pugh, M. 2005. "The Political Economy of Peacebuilding: A Critical Theory Perspective." International Journal of Peace Studies. Vol. 10, No. 2, pp. 23-42.

Pugh, M. 2011. "Local Agency and Political Economies of Peacebuilding." Studies in Ethnicity and Nationalism. Vol. 11, No. 4, pp. 308-320.

Pugh, M., N. Cooper, and M. Turner, eds. 2008. Whose Peace? Critical Perspectives on the Political Economy of Peacebuilding. London: Palgrave.

Ramnarain, S. 2011. "Women's Cooperatives and Peace in India and Nepal." International Research Series. Toronto: Canadian Cooperatives' Association.

Richmond, O. 2006. "The Problem of Peace: Understanding the 'Liberal Peace'." Conflict, Security and Development. Vol. 6, No. 3, pp. 291-314.

Richmond, O. 2009. "Becoming Liberal, Unbecoming Liberalism: Liberal-Local Hybridity via the Everyday as a Response to the Paradoxes of Libera Peacebuilding." Journal of Intervention and Statebuilding. Vol. 3, No. 3, pp. 324-344.

Richmond, O. 2010. "Resistance and the Post-Liberal Peace." Millennium: Journal of International Studies. Vol. 38, No. 3, pp. 665-692.

Richmond, O. and J. Franks. 2008. "Liberal Peacebuilding in Timor-Leste: The Emperor's New Clothes?” International Peacekeeping. Vol. 15, No. 2, pp. 185-200.

Ruwanpura, K. 2007. “Awareness and Action: The Ethno-Gender Dynamics of Sri Lankan NGOs." Gender, Place and Culture: A Journal of Feminist Geography. Vol. 14, No. 3, pp. 317-333.

Sentama, E. 2009. "Peacebuilding in Post-Genocide Rwanda: The Role of Co-operatives in the Restoration of Interpersonal Relationships." Ph.D. Thesis University of Gothenburg: School of Global Studies. Sweden.

Shima, S. and Y. Ghale. 2007. "Building Hope while Providing Credit Through 
Co-operatives: A Case Study of Women Coping with Conflict in Nepal," pp. 207215 in J. Emmanuel and I. MacPherson, eds. Co-operatives and the Pursuit of Peace. British Columbia Institute of Co-operative Studies. [City]: New Rochdale Press.

Suhrke, A. 2008. "Democratizing a Dependent State: The Case of Afghanistan." Democratization. Vol. 15, No. 3, pp. 630-648.

Wehnert, U. and R. Shakya. 2003. "Microfinance and Armed Conflict in Nepal: The Adverse Effects of the Insurgency on the Small Farmer Cooperatives Ltd. (SFCLs)." Working Paper No. 3. Kathmandu: Rural Finance Nepal.

Weihe, T. 2004. Co-operatives in Conflict and Failed States. Washington, D.C.: United States Overseas Co-operative Development Council.

Whyte, W.F. and K.K. Whyte. 1991. Making Mondragon. 2nd rev. ed. Ithaca, NY: ILR Press.

Woodward, S. 1995. Balkan Tragedy: Chaos and Dissolution after the Cold War. Washington, D.C.: Brookings Institution. 